\title{
PROSES FINISHING PEMBUATAN KAPAL PAJEKO \\ (MINI PURSE SEINER) DI KAMPUNG PARA I KECAMATAN TATOARENG
}

\author{
Finishing Process of Purse Seiner Shipbuilding in Para I Village Tatoareng District
}

\author{
Julius Frans Wuaten, Ishak Bawias, Rafles Kawowode \\ Program Studi Teknologi Penangkapan Ikan, Jurusan Perikanan dan Kebaharian, Politeknik Negeri Nusa Utara, \\ Email: odewuaten@gmail.com
}

\begin{abstract}
Abstrak: . Salah satu lokasi tempat pembuatan kapal penangkap ikan yang ada di Kabupaten Kepulauan Sangihe yaitu di Kampung Para I Kecamatan Tatoareng. Masyarakat nelayan yang ada di Kampung Para I pada umumnya memiliki kemampuan dan keahlian dalam membuat unit perahu/kapal penangkap ikan yang diperolehnya secara turun temurun dari orang tua dan nenek moyang mereka. Hampir setiap tahun, nelayan pembuat kapal di Kampung Para I memproduksi kapal penangkap ikan dari bahan kayu, pesanan dari nelayan yang ada di sekitar Pulau Para maupun dari luar pulau. Penelitian ini dilakukan untuk melihat secara langsung proses pembuatan kapal penangkap ikan dari bahan kayu, khususnya dalam proses finishing kapal pajeko. Metode yang digunakan yaitu metode deskriptif, dengan menggambarkan atau menguraikan kejadian di lapangan dalam bentuk laporan, tanpa mengurangi atau menambah informasi yang ada di lapangan. Teknik pengumpulan data dilakukan dengan melakukan wawancara dengan nelayan pembuat kapal, pengamatan langsung dan partisipasi dalam proses finishing meliputi pemakalan, pendumpulan, dan pengecatan kapal. Proses finishing dalam pembuatan kapal pajeko berbahan baku kayu di Kampung Para 1 Kecamatan Tatoreng semuanya dilakukan secara tradisional dan pengerjaannya dilakukan oleh nelayan setempat, mulai dari proses memakal, mendempul dan mengecat dengan peralatan yang sederhana.
\end{abstract}

Kata kunci: Kapal kayu, finishing, nelayan, Kampung Para I

Abtract: One of the locations for fishing boats in Sangihe Islands Regency is Para Village 1, Tatoareng District. The fishing communities in Para Village 1 generally have the ability and expertise to build fishing boats / vessels, which they have from generation to generation from their parents and ancestors. Almost every year, fishermen who build boats in Para I Village produce fishing boats made of wood, orders from fishermen around Para Island and from outside the island. This research was conducted to see firsthand, the process of making fishing boats from wood, especially in the finishing process of the pajeko boat. The method used is descriptive method, by describing the events in the field, to the form of reports, without reducing or adding to the information in the field. Data collection techniques are carried out by conducting interviews with shipbuilders, direct observation and participation in the shipbuilding finishing process including 'pemakalan', 'pendumpulan', and ship painting. The finishing process in making pajeko boats made of wood in Para Village 1, Tatoreng District, is all done traditionally and the work is done by local fishermen, starting from the process of 'pemakalan', 'pendumpulan' and painting with simple equipment.

Keyword: $\quad$ Wooden boats, shipbuilding finishing proccess, fishermen, Kampung Para I 


\section{PENDAHULUAN}

Perairan laut Sulawesi Utara sering dijumpai banyak kapal purse seine yang beroperasi dengan ukuran yang lebih kecil dan berpangkalan di Pelabuhan Bitung. Masyarakat nelayan dan pengusaha ikan di Sulawesi Utara khususnya Kota Bitung sering menyebutnya dengan nama kapal pukat cincin kecil (small purse seiner) atau kapal pajeko (Pamikiran, 2013). Umumnya kapal penangkap ikan yang ada di Sulawesi Utara dibangun dan dirancang secara tradisional dengan menggunakan bahan kayu (Tumiwa, 2012).

Provinsi Sulawesi Utara sebagai salah satu sentra industri perikanan di Indonesia, memiliki beberapa lokasi atau tempat yang mampu menghasilkan produk kapal penangkap ikan tradisional berbahan baku kayu yang sudah teruji dan diakui karena mampu beroperasi sampai di perairan kawasan Indonesia Timur. Salah satu lokasi tempat pembuatan kapal penangkap ikan yang ada di Propinsi Sulawesi Utara yaitu di Kabupaten Kepulauan Sangihe, tepatnya di Kampung Para I Kecamatan Tatoareng. Menurut Iskandar dan Novita (2000) dalam Rusmilyansari (2014), menjelaskan bahwa istilah tradisional lebih mengarah kepada metode atau cara yang digunakan oleh para pengrajin kapal perikanan dalam mengkonstruksi kapal buatannya, dimana caracara atau metode yang diterapkan merupakan warisan para pendahulunya.

Kapal perikanan merupakan kendaraan utama nelayan untuk menuju ke fishing ground dan mengangkut alat tangkap seperti purse seine. Alat tangkap purse seine juga merupakan alat tangkap yang menangkap ikan bersifat schooling fish, sehingga harus memiliki kapasitas besar dan desain yang sesuai dengan alat tangkap (Azis, 2017). Menurut Peraturan Menteri Kelautan dan Perikanan Republik Indonesia nomor 10/PERMEN-KP/2019 tentang Sistem Pemantauan Kapal Perikanan, Kapal Perikanan adalah kapal, perahu, atau alat apung lain yang dipergunakan untuk melakukan penangkapan ikan, mendukung operasi penangkapan ikan, pembudidayaan ikan, pengangkutan ikan, pengolahan ikan, pelatihan perikanan, dan penelitian/eksplorasi perikanan. Ardidja (2007) menerangkan bahwa, kapal pukat cincin umumnya berbentuk ramping dengan geladak kerja di bagian buritan, ruang kemudi dan akomodasi di bagian haluan, bangunan slipway di buritan sebagai tempat penyimpan dan peluncuran skiff boat. Kapal-kapal ini merupakan kelompok terbesar yang berukuran kecil hingga kapal yang berlayar ke samudra (open oceangoing vessels). Desain konstruksi suatu kapal penangkap ikan mempengaruhi kenerja dan umur teknis kapal tersebut dalam pengoperasian kapal tersebut. Faktor-faktor yang mempengaruhi desain kapal penangkap ikan adalah tujuan penangkapan, alat dan metode penangkapan, kelayak-lautan dari kapal tersebut dan keselamatan awak kapal. Peraturan yang berhubungan dengan desain kapal, pemilihan material yang tepat untuk konstruksi, penanganan dan penyimpanan hasil tangkapan dan faktor ekonomi (Fyson, 1985 dalam Mullah, 2010).

Salah satu contoh kontruksi kapal pure seine yang di paparkan oleh Rizwan (2017), material atau bahan pembuatan kapal purse seine di Lampulo seluruhnya menggunakan kayu. Kayu-kayu yang digunakan pada konstruksi kapal harus memiliki sifat yang baik karena kapal akan selalu berada di dalam air dan harus tahan terhadap serangan hewan laut seperti kapang dan teritip. Jenis kayu yang digunakan pada pembangunan kapal purse seine yaitu kayu bangkirai, kayu laban. Material kapal merupakan bahan dasar yang harus ada sebelum pembangunan kapal dilakukan. Pemilihan material kapal harus mempertimbangkan berbagai aspek seperti kekuatan, keawetan, ketahan, kualitas, dan ukuran yang dibutuhkan dari pada pembangunan kapal (Iskandar, 1990 dalam Rizwan, 2017).

Masyarakat nelayan yang ada di Kampung Para I pada umumnya memiliki kemampuan dan keahlian dalam membuat unit perahu/kapal penangkap ikan yang diperolehnya secara turun-temurun dari orang tua dan 
nenek moyang mereka. Berdasarkan data yang diperoleh dari hasil survey awal diperoleh keterangan bahwa di Kampung Para I nelayan pembuat kapal berbahan kayu berjumlah 8 (delapan) orang yang juga berprofesi sebagai tukang yang dibantu oleh 15 (lima belas) orang pembantu tukang (kenek). Hampir setiap tahun nelayan pembuat kapal di Kampung Para I memproduksi kapal penangkap ikan dari bahan kayu, pesanan dari nelayan yang ada di sekitar Pulau Para maupun dari luar pulau.

Rumusan masalah pada penelitian ini yaitu bagaimana proses finishing dalam pembuatan kapal pajeko (mini purse seiner) di Kampung Para I Kecamatan Tatoareng? Tujuan penelitian ini yaitu mengetahui proses finishing dalam pembuatan kapal pajeko di Kampung Para I Kecamatan Tatoareng.

\section{METODE PENELITIAN}

Penelitian ini dilaksanakan selama 3 (tiga) bulan dimulai dari Bulan Mei sampai Bulan Juli 2020 di Kampung Para I Kecamatan Tatoareng, ditunjukkan pada Gambar 1.

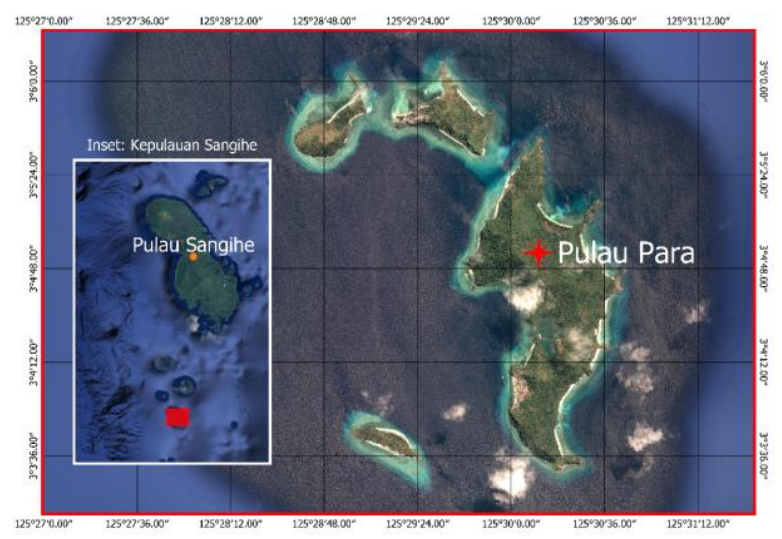

Gambar 1. Pulau Para-Kabupaten Kepulauan Sangihe

Alat dan bahan yang digunakan selama pelaksanaan penelitian tertera pada Tabel 1 .
Tabel 1. Alat dan Bahan Penelitian

\begin{tabular}{|c|c|c|c|}
\hline No & $\begin{array}{c}\text { Alat } \\
\text { Penelitian }\end{array}$ & Jumlah & Kegunaan \\
\hline 1 & $\begin{array}{l}\text { Alat tulis } \\
\text { menulis }\end{array}$ & 1 set & $\begin{array}{l}\text { Untuk mencatat data hasil pengamatan } \\
\text { selama penelitian }\end{array}$ \\
\hline 2 & Kamera (HP) & 1 unit & Untuk mengambil gambar dokumentasi \\
\hline 3 & Pahat & 4 buah & $\begin{array}{l}\text { Alat pakal untuk memasukkan benang } \\
\text { kedalam celah antar papan lambung } \\
\text { kapal dan geladak }\end{array}$ \\
\hline 4 & Palu & 2 buah & $\begin{array}{l}\text { Untuk memberikan tumbukan kepada } \\
\text { pahat dalam proses memakal }\end{array}$ \\
\hline 5 & Scraper & 4 buah & $\begin{array}{l}\text { Alat untuk memoles bahan dempul pada } \\
\text { kayu }\end{array}$ \\
\hline 6 & Gerinda listrik & 1 unit & $\begin{array}{l}\text { Untuk mempercepat proses mengamplas } \\
\text { kayu }\end{array}$ \\
\hline 7 & Kuas & 4 buah & Alat untuk mengecat kapal pajeko \\
\hline No & $\begin{array}{c}\text { Bahan } \\
\text { Penelitian }\end{array}$ & Jumlah & Kegunaan \\
\hline 1 & Benang jute & $20 \mathrm{~kg}$ & $\begin{array}{l}\text { Bahan untuk menutup celah antara papan } \\
\text { kulit lambung kapal dan lantai geladak }\end{array}$ \\
\hline 2 & Dempul Epoxy & 6 kaleng & Bahan untuk mendempul \\
\hline 3 & $\begin{array}{l}\text { Plamir (merk } \\
\text { Boyo) }\end{array}$ & 4 kaleng & $\begin{array}{c}\text { Bahan yang dicampur pada Epoxy untuk } \\
\text { mempercapat dan menghemat bahan } \\
\text { dempul }\end{array}$ \\
\hline 4 & Ampelas & $\begin{array}{c}15 \\
\text { lembar }\end{array}$ & $\begin{array}{l}\text { Untuk meratakan dan memperhalus } \\
\text { permukaan kayu }\end{array}$ \\
\hline 5 & $\begin{array}{c}\text { Cat Kayu } \\
\text { (merk Glo-tex) }\end{array}$ & $\begin{array}{c}20 \\
\text { kaleng }\end{array}$ & $\begin{array}{l}\text { Sebagai bahan cat kapal pajeko } \\
\text { melindungi kayu dari perubahan cuaca }\end{array}$ \\
\hline 6 & $\begin{array}{c}\text { Minyak Cat } \\
\text { (merk Thinner) }\end{array}$ & $\begin{array}{c}20 \\
\text { kaleng }\end{array}$ & Bahan untuk mencampur cat dan \\
\hline
\end{tabular}

Metode yang digunakan dalam penelitian ini yaitu metode deskriptif. Metode deskriptif adalah metode yang menggambarkan atau menguraikan kejadian di lapangan dalam bentuk laporan, tanpa mengurangi atau menambah informasi yang ada di lapangan (Sukmadinata, 2008). Teknik pengumpulan data dilakukan dengan melakukan wawancara terhadap nelayan pembuat kapal, pengamatan langsung dan partisipasi aktif dalam proses finishing, serta melakukan pencatatan dan pengambilan gambar pada saat proses pembuatan kapal pajeko khususnya pada proses pemakalan.

Data tentang proses pendumpulan dan pengecatan kapal diperoleh penulis dengan hanya melakukan wawancara kepada nelayan pembuat kapal, karena proses pendumpulan dan pengecatan belum dilaksanakan pada saat penelitian ini dilakukan. Sedangkan data sekunder yaitu data yang dikumpulkan untuk maksud menyelesaikan masalah yang sedang dihadapi yang diperoleh dari literatur, artikel, jurnal dan data Kampung Para I. Analisis data dilakukan untuk dapat menjelaskan suatu proses atau tahapan dalam 
pembuatan kapal pajeko yang ada di Kampung Para I khususnya pada proses finishing berdasarkan data primer yang dikumpulkan kemudian ditampilkan dalam bentuk tabel bahan dan alat yang digunakan dan proses pemakalan, pendumpulan dan pengecatan kapal pajeko yang dilengkapi dengan gambar hasil dokumentasi.

\section{HASIL DAN PEMBAHASAN}

Kapal Pajeko yang menjadi objek pengamatan di Kampung Para 1 Kecamatan Tatoareng, seluruh konstruksinya terbuat dari bahan kayu. Bahan kayu yang digunakan terdiri dari beberapa jenis kayu yang penempatannya sesuai dengan fungsi dan kekuatannya. Berdasarkan fungsi/kegunaannya dan kekuaatannya, maka jenis kayu yang digunakan dalam pembuatan kapal pajeko di Kampung Para I antara lain:

1) Kayu Bunaro yang digunakan sebagai lunas kapal;

2) Kayu Gopasa (Vitex Cofassue) digunakan untuk linggi depan dan gading kapal;

3) Kayu Kamaluang digunakan sebagai papan kulit lambung kapal diatas lunas sampai papan ke 3 (tiga);

4) Kayu Pilapihe digunakan sebagai papan kulit lambung kapal papan 4 (empat) sampai papan 13 (tiga belas);

5) Kayu Kapuraca / Dingkaleng (Callophyllum inophyllum) digunakan untuk bagian sheer kapal;

6) Kayu Malengku digunakan untuk geladak;

7) Kayu Nato digunakan untuk deck atas.

Dalam penelitian ini, untuk jenis kayu Bunoro, Gopasa, Kamaluang, Pilapihe, Malengku dan Nato, penulis hanya menyertakan nama lokal berdasarkan informasi yang didapatkan langsung dari data penelitian dilapangan berupa hasil wawancara dengan nelayan pembuat kapal tersebut. Selain itu, literatur-literatur yang menjelaskan ciri dan karakteristik kayu-kayu tersebut masih sulit ditemukan sehingga proses identifikasi nama ilmiah jenis kayu tersebut belum dapat dilakukan..

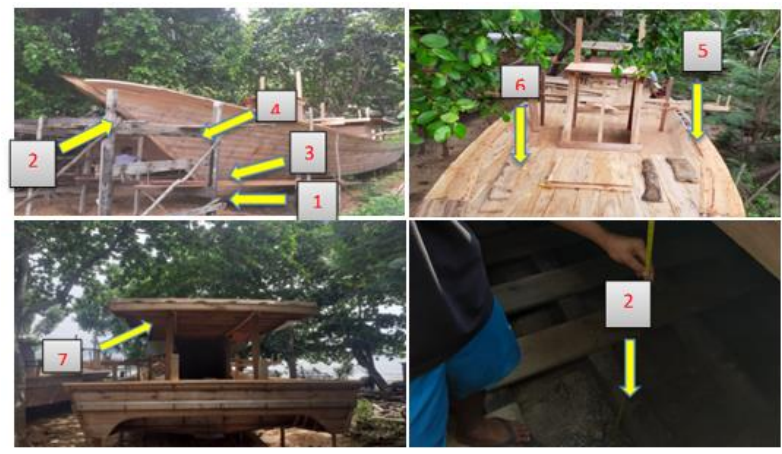

Gambar 2. Penggunaan Jenis Kayu berbeda sesuai Fungsinya dalam Pembuatan Kapal Pajeko

Kapal pajeko yang menjadi objek pengamatan di Kampung Para I memiliki ukuran panjang keselurahan (LOA) 19.66 Meter, Lebar (Breadth) 4 Meter, Dalam (Depth) 1,4 Meter.

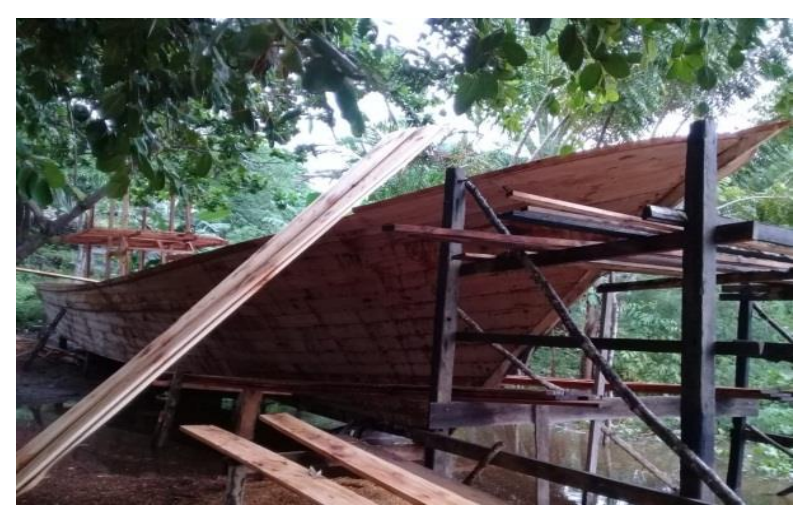

Gambar3. Kapal Pajeko di Kampung Para 1

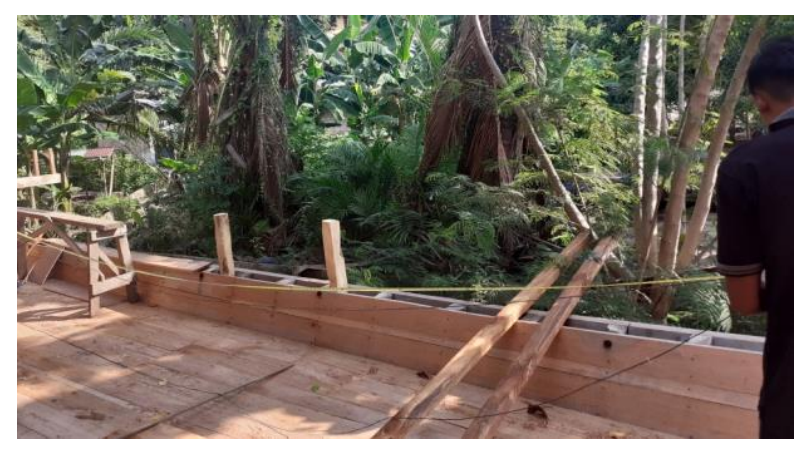

Gambar 4. Pengukuran Panjang, lebar dan dalam kapal

Proses finishing dalam pembuatan kapal pajeko yang ada di Kampung Para 1 Kecamatan Tatoareng meliputi pekerjaan: pemakalan, pendumpulan dan pengecatan. 


\section{Pekerjaan Pemakalan}

Pekerjaan pemakalan dilakukan setelah pemasangan papan kulit luar lambung kapal pajeko. Menurut Kamus Besar Bahasa Indonesia (KBBI, 2009) kata pakal artinya kulit kayu, sabut dan lain sebagainya yang digunakan untuk menutup celah-celah papan yang ada di geladak atau di dinding perahu/kapal. Sedangkan memakal artinya pekerjaan menutup celah-celah papan geladak atau dinding perahu dengan sabut. Bahan yang digunakan untuk memakal celah-celah papan di geladak maupun di dinding kapal pajeko yaitu dari bahan serabut benang yang dilakukan oleh nelayan di Kampung Para 1 menggunakan bahan tali jute yang terbuat dari serat jute yang banyak tumbuh di Negara India. Serat ini banyak digunakan sebagai bahan karung yang memilki warna coklat muda, banyak menyerap air, mudah lapuk dan tidak terlalu kuat sehingga serat ini hanya digunakan sebagai bahan pembuat karung goni dan tali pakal yang banyak digunakan dalam pembuatan kapal tradisional (Santoso, 2012). Oleh masyarakat nelayan lokal Sangihe tali jute dikenal dengan sebutan tali karong, karena bahannya sama dengan bahan pembuat karung goni.
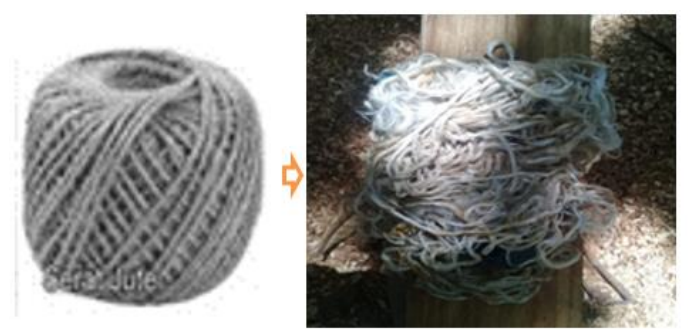

Gambar 5. Benang Jute sebagai Bahan untuk Memakal Kapal Pajeko

Untuk mendapatkan hasil yang baik, nelayan menggunakan peralatan untuk memakal yaitu pahat dari bahan besi yang dalam 26ahasa daerah Sangihe disebut papakale dan palu atau martelu dari material besi dan kayu.

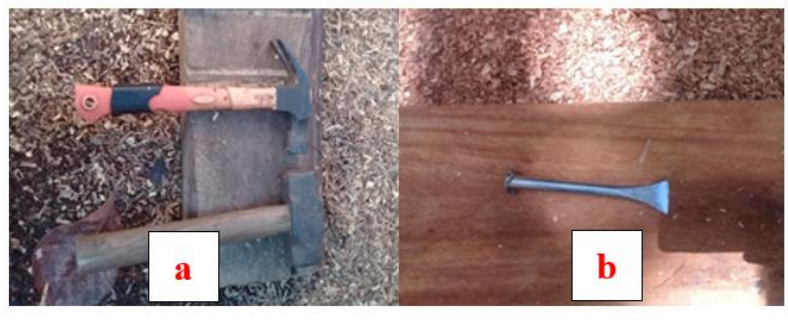

Gambar 6. Peralatan Untuk Memakal (a) palu/martelu (b) pahat/papakale

Proses pemakalan kapal pajeko di Kampung Para 1 dimulai dari memakal celah papan kulit lambung kapal bagian bawah yang berada tepat diatas lunas. Kemudian dilanjutkan dengan pemakalan pada celah antara papan yang ada diatas lunas kapal sebanyak 16 lembar papan kulit luar lambung kapal sampai ke bagian sheer yang berada diatas deck. Pemakalan dilakukan dengan cara merentangkan benang jute dan disejajarkan pada celahcelah papan kulit lambung kapal kemudian benang jute dimasukkan kedalam celah antar papan kulit lambung kapal dengan menggunakan pahat yang ditumbuk dengan palu sampai semua celah tersebut tertutup rapat dan padat dengan benang jute.

\section{Pekerjaan Pendumpulan}

Proses pendumpulan pada finishing pembuatan kapal pajeko dilakukan setelah pekerjaan pemakalan seluruh lambung kapal, sheer, lantai kapal (deck) dan geladak telah selesai. Langkah pertama dalam proses pendumpulan yaitu melakukan pembersihan seluruh permukaan papan atau badan kapal meliputi lunas, lambung kapal, linggi depan dan belakang, sheer, geladak, buritan, haluan dan lantai kapal (deck). Selanjutnya setelah seluruh permukaan kayu pada bangunan kapal selesai dibersihakan dilanjutkan dengan mencampur bahan untuk dempul kayu, yaitu epoxy hardener dan resin hingga merata dan warnanya menjadi homogen. Setelah proses pencampuran bahan epoxy hardener dan resin selesai, untuk mempercepat proses pendumpulan dan menghemat bahan dempul, oleh 
nelayan pembuat kapal ditambahkan bahan plamir merek boyo berupa cairan putih yang biasanya merupakan campuran kalsium, lem dan resin.

Setelah proses percampuran bahan dempul selesai, maka dilanjutkan dengan persiapan wadah untuk mengoleskan dempul yang terbuat dari plastik bekas wadah minyak pelumas mesin (oli). Bahan dempul kemudian dioleskan pada permukaan kayu yang akan didempul seperti celah antar papan, sambungan papan, pori kayu dan lubang bekas paku sampai merata. Proses pendumpulan ini selain meratakan permukaan badan kapal dan menutup lubang dan pori kayu juga dapat mengurangi bahan yang digunakan dalam pengecatan. Pekerjaan pendumpulan dapat dilihat pada tampilan Gambar 7.
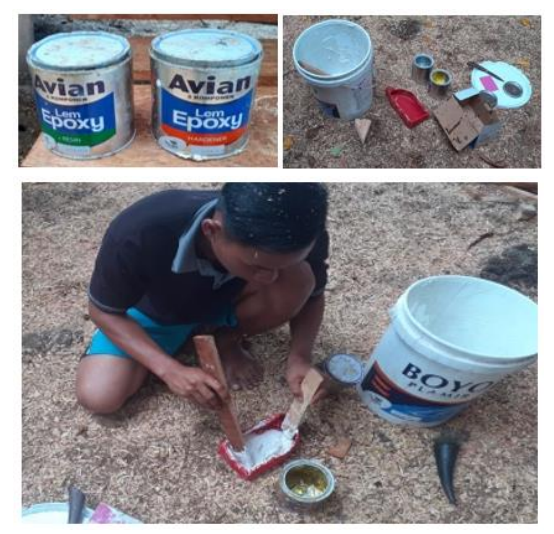

Gambar 7. Bahan dempul dan alat yang digunakan dalam pendumpulan

Setelah proses penutupan lubang sambungan dan pori pada kayu selesai sampai didempul merata, kemudian dilakukan pengampelasan menggunakan gurinda yang ditambahkan lembaran ampelas untuk menghaluskan permukaan kayu yang telah didempul sebelum dilakukan pengecatan.

\section{Pekerjaan Pengecatan}

Pekerjaan pengecatan kapal pajeko dilakukan setelah semua proses pendumpulan dan pengampelasan selesai dikerjakan dan permukaan kayu sudah rata dan halus. Proses pengecatan seluruh body kapal pajeko membutuhkan 20 kaleng cat minyak merek glo-tex volume 1 liter. Minyak cat yang digunakan merek Thinner sebanyak 20 liter. Dengan demikian, maka perbandingan antara cat dan minyak cat yaitu $1: 1$.

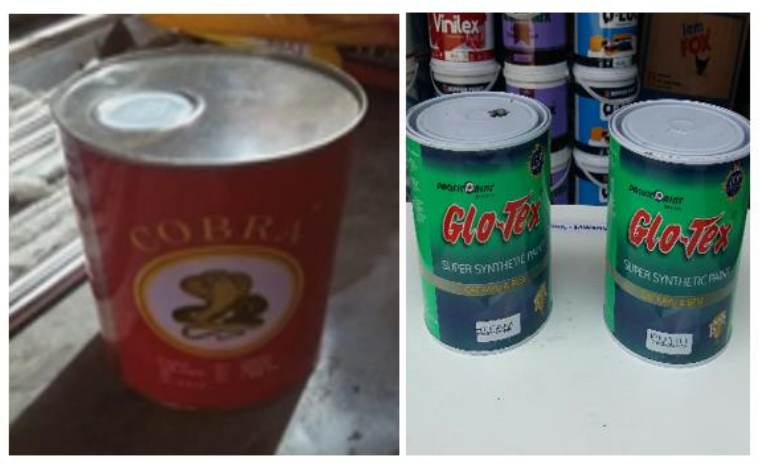

Gambar 8. Cat Glo-tex dan Minyak Cat (Thinner)

Dari hasil wawancara dengan pembuat kapal pajeko diperoleh informasi bahwa pekerjaan pengecatan kapal pajeko biasanya dilakukan pada saat cuaca cerah pada pagi hingga sore hari agar cat lebih cepat mengering dengan bantuan sinar matahari.

\section{KESIMPULAN}

Kesimpulan yang diperoleh selama melaksanakan penelitian ini yaitu bahwa proses finishing dalam pembuatan kapal pajeko berbahan baku kayu di Kampung Para 1 Kecamatan Tatoreng semuanya dilakukan secara tradisional dan pengerjaannya dilakukan dalam tiga tahap yaitu pemakalan, pendempulan dan pengecatan. Seluruh proses pengerjaan dikerjakan oleh nelayan setempat yang menjadi pekerja di tempat tersebut.

\section{DAFTAR RUJUKAN}

Ardidja, S. 2007. Kapal Penangkap Ikan. Sekolah Tinggi Perikanan, Teknologi Penangkapan Ikan. Jakarta. Azis, M.A, Iskandar, dan Novita (2017) Kajian Desain Kapal Purse Seine Tradisional di Kabupaten Pinrang (Study Kasus Km. Cahaya Arafah) Mahasiswa Program Pasca Sarjana Departemen PSP FPIK IPB 2 Departemen PSP FPIK IPB. 
Kamus Besar Bahasa Indonesia Edisi III. 2001. Departemen Pendidikan Nasional. Balai Pustaka. Jakarta.

Mullah., A (2010). Kesesuaian Ukuran Beberapa Bagian Konstruksi Kapal Penangkap Ikan di PPN Pelabuhan Ratu Jawa Barat Dengan Aturan Biro Klasifikasi Indonesia. Institut Pertanian Bogor

Pamikiran., R.D Ch (2013). Penggunaan Mesin Penggerak Kapal Pukat Cincin KM. Maestro. Jurnal Perikanan dan Kelautan Tropis. Volume XII-2. Universitas Sam Ratulangi. Manado.

Rusmilyansari, Iriansyah dan Aminah (2014). Pembangunan Kapal Perikanan di Galangan Kapal Tradisional Kalimantan Selatan. Program Studi Pemanfaatan Sumberdaya Perikanan Fakultas Perikanan dan Kelautan Universitas Lambung Mangkurat.

Rizwan, Setiawan, Rahimi, Dewiyanti, Purnama, Arif, (2017) Desain Dan Studi Konstruksi Kapal Purse Seine Bermaterial Kayu di Pelabuhan Perikanan
Samudera (Pps) Lampulo. Fakultas Kelautan dan Perikanan Universitas Syiah Kuala, Banda Ace Santoso., A, Semin, dan Saman M.B. 2012. Permesinan Bantu Pada Kapal Modern.Volume 1: Permesinan Geladak. Buku Berseri Teknologi Permesinan Kapal. Airlangga University Press. Surabaya Sukmadinata, Nana syaodih. 2008. Metode penelitian Pendidikan. Bandung: PT Remaja Rosdakarya

Tumiwa, Masengi dan Pamikiran (2012). Stabilitas Dinamis Kapal Pukat Cincin di Sulawesi Utara. Jurnal Perikanan dan Kelautan Tropis. Volume VIII-3. Universitas Sam Ratulangi. Manado.

Republik Indonesia. 2019. Peraturan Menteri Kelautan dan Perikanan Republik Indonesia nomor 10/PERMEN-KP/2019 tentang Sistem Pemantauan Kapal Perikanan. Lembaran Negara Republik Indonesia Nomor 5. Sekretariat Negara. Jakarta. 